\title{
P 23
}

\section{ライフスタイルと包括的ストレス評価に関する認知行動学的研究 （第 8 報）自覚的ストレスに関わる要因の検討}

○福田早苗・丸山総一郎・森本兼暴 （阪大・医・環境医学）

【目的】近年、労動環境が複雑になり、それに伴い様々な心身面での問題が生じていると考えられる。本研究では、 労働者の心身面の問題について、最も簡単なストレスを非ねる項目である「自覚的ストレス」に関わる要因及び、喠 液中コルチゾールとの関連についてを検討した結果を報告する。

【方法】調査は1997 年 7 月、睡液採取及び自記式質問紙 回答に協力するという了承を得られた対象者 123 名に対し て行った。質問内容は自賞的ストレスを含むライフスタイ ル項目、川上らの日本語版仕事ストレス JCO (Job Content Questionnaire)、ラザルスのストレス対処 14 項目、通勤 時間、残業時間等であった。同時に喠液を採取し、コルチ ゾールをEILSA 法（CIRON 社製）にて測定した(1)。唾液は Salivet te(SARSTEDT 社製)を用いて 8 時 30 分〜10 時に採 取した。

【結果】自覚的ストレスが多い群ではストレスの少ない。 普通群に比べて唾液中コルチゾールが高い傾向が見られた （図 1)。自覚的ストレスにの多い群では仕事の要求度が 高いが、仕事の裁量権は変わらず、同僚・上司・社会・家 族のサポート点数は变わらなかった。また、消極的ストレ ス対処行動が少ない・普通群に比べて多い傾向にあった。 残業時間も少ない・普通群に比べて長い傾向にあった（表 1)。自覚的ストレスの多い群では少ない・普通群に比べ て労働時間が長く、6ヶ月前より体調が悪く、適正な睡眠 時間が守られておらず、食事・生活ともに不規則で、栄養 バランスが覀く、運動習慣がないものが多い傾向が明らか になった（表2)。

【結論】労働者の自覚的ストレスは隀液中コルチゾールと 関連があり、自覚的ストレスを增やす要因には仕事の要 求・残業時間・学働時間などの労㣫環境に関わる要因が強 く、規則正しい生活や運動習慣によりストレスが緩和され る可能性と自覚的ストレスがあると身体的にも不調を訴え る傾向にあることが示陖された。

(1)Shimada M et al. Horm Res 1995;44:213-17.
* $\mathrm{P}<0.05$ Wilcoxon Rank Sum W Test

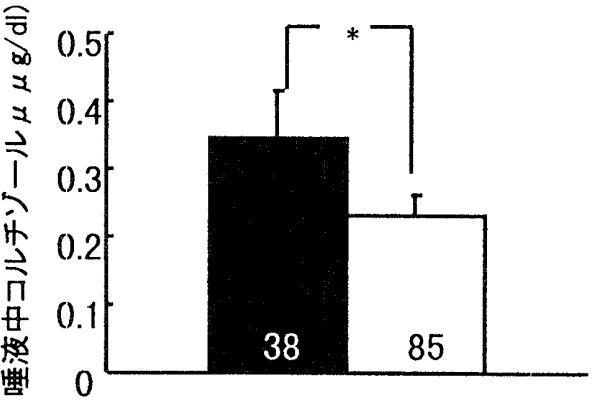

多い 少ない・普通

自賞的ストレス

図1 自覚的ストレスと唾液中コルチゾールの関係

表 1 自賞的ストレスと労働条件の関係

\begin{tabular}{|c|c|c|c|}
\hline \multirow[b]{2}{*}{ 項目(平均土S.E) } & \multicolumn{2}{|c|}{ 自賞的六卜レス } & \\
\hline & 多 $W(N=34)$ & 少ない普通 $(N=84)$ & \\
\hline 交替勤務有 $(\%)$ & $0.00(0)$ & $4.71(4)$ & \\
\hline 職位(管理職) $(\%)$ & $34.21(13)$ & $23.81(20)$ & \\
\hline （)内は满点を表す & & & t唡定 \\
\hline 仕事の裁量権得点 (96) & $69.84 \pm 2.10$ & $67.56 \pm 1.07$ & \\
\hline 仕事の要求度得点 (48) & $36.26 \pm 0.94$ & $32.12 \pm 0.50$ & $* * * *$ \\
\hline 同像のサポート得点(16) & $10.95 \pm 0.40$ & $11.31 \pm 0.17$ & \\
\hline 社会のサポート得点(32) & $21.79 \pm 0.76$ & $22.15 \pm 0.35$ & \\
\hline 家族のサポート得点(16) & $11.53 \pm 0.35$ & $11.16 \pm 0.18$ & \\
\hline 消極的ストレス対如得点 (21) & $4.45 \pm 0.66$ & $3.43 \pm 0.39$ & \\
\hline 皘崡的ストレス対姑得点(21) & $6.97 \pm 0.70$ & $6.20 \pm 0.46$ & \\
\hline 通勤時間 & $53.06 \pm 6.02$ & $55.76 \pm 2.91$ & \\
\hline 残;業時間 & $31.92 \pm 3.04$ & $20.55 \pm 1.96$ & $*$ \\
\hline
\end{tabular}

表2 自賞的ストレスとライフスタイルの関係

\begin{tabular}{|c|c|c|c|}
\hline \multirow[b]{2}{*}{ 項目 } & \multicolumn{2}{|c|}{ 自堂的잔즈 $(\%)$} & \multirow{2}{*}{$x^{2}$ 険定 } \\
\hline & $\xi(1 \%(N=38)$ & 少ない・萛通\%(N=85) & \\
\hline 朝食を取らない & $5.26(2)$ & $11.76(10)$ & \\
\hline 間食をする & $5.26(2)$ & $2.35(2)$ & \\
\hline 程分をひかえない & $60.53(23)$ & $63.53(54)$ & \\
\hline 労衝時間(10h以上) & $34.21(13)$ & $20.00(17)$ & $\dagger$ \\
\hline 趣味がない & $21.05(8)$ & $10.59(9)$ & \\
\hline 代しい & $89.47(34)$ & $84.52(71)$ & \\
\hline $\begin{array}{l}\text { 6ヶ月前より体調悪い } \\
\text { 每:日酒を飲む }\end{array}$ & $\begin{array}{l}18.42(7) \\
59.46(22)\end{array}$ & $\begin{array}{r}3.53(3) \\
4588(39)\end{array}$ & $* * *$ \\
\hline 㗪煙者 & $55.26(21)$ & $48.24(41)$ & \\
\hline 睡眠時間(6h以下or9h以 & 上) $64.86(24)$ & $49.41(42)$ & $\dagger$ \\
\hline 县:事が不規則 & $31.58(12)$ & $18.82(16)$ & $\dagger$ \\
\hline 栄:莨バランスが覀い & $68.42(26)$ & $81.18(69)$ & $\dagger$ \\
\hline 生活が不規則 & $34.21(13)$ & $14.29(12)$ & $* *$ \\
\hline 連動をほとんどしない & $84.21(32)$ & $57.65(49)$ & $* * *$ \\
\hline
\end{tabular}

